\title{
INFORMAL ECONOMY AND PEACEBUILDING EFFORTS AMONG MUSLIM AND CHRISTIAN COMMUNITIES DURING COMMUNAL CONFLICTS IN AMBON
}

\author{
Abellia Anggi Wardani \\ Universitas Indonesia, Depok, Indonesia \\ E-mail: abellia@ui.ac.id
}

\begin{abstract}
Communal conflicts that happened in Ambon, eastern part of Indonesia more than 20 years ago still reserve a lot of lessons to unveil. One of the least discussed issues is the roles of economic exchanges among diverse community members in bringing peace from below. This article tries to capture the interreligious interactions (Muslim and Christian) among buyers and sellers in areas considered as border space during the conflicts from 1999 to 2004. It showcases the intertwin of everyday peacebuilding efforts through trade and the spread of peace messages among those involved in the exchange practices. This research employed qualitative research methods using ethnographic strategy with indepth interview, observation, and library study. Data was collected from 2016-2019 including 10-month intensive fieldwork. The article discusses that social networks and cultural ties embedded in the economic drivers of traderelated activities arguably set the foundation for everyday peacebuilding. In conclusion, economic transactions allowed interethnic, intervillage, and interreligious interactions to take place, eliminated distrust among the traders, and potentially extended peace message narratives at the micro level such as among family members.
\end{abstract}

Keywords: Informal economies; Muslim community; communal conflicts; Ambon; Indonesia

\section{Introduction}

Maluku has long been associated with wars, fractions, and tensions over the transfer of power, traditionally as well as from a contemporary standpoint. People tend to unconsciously possess the idea that since conflicts occurred in the past, future outbreaks 
would, perhaps, be just around the corner. ${ }^{1}$ Not long after the continuous attempts to conquer the islands due to the infamous nutmeg discovery in the $16^{\text {th }}$ century, peace and order in Maluku were just as rare as nutmeg in the Western world at that time. ${ }^{2}$

In 1997, Indonesia was one of the countries most impacted by the Asian financial crisis (AFC) and the GDP experienced a "catastrophic contraction of $13.1 \%$ in 1998, followed by negligible growth in 1999." In a recent report published by the International Monetary Fund (IMF), Basri argued that Indonesia's weak responses to the AFC was due to its banking sector being weak. ${ }^{4}$ The unstable political climate in 1998 due to the fall of the Soeharto government worsened the economic crisis. Indonesia then entered a brand-new phase of its existence and evolved into a democratic country due to the reformation movement. Amirrachman argued that decentralization, as a part of the flagship product of the reformation era, resulted in exaggerated euphoria, especially among the native people who had the opportunity to assume power. ${ }^{5}$ This increased the dichotomy between the natives and migrants, fearing that equal opportunity in politics would reduce the native people's chance to remain in power after three decades of centralization. ${ }^{6}$

\footnotetext{
${ }^{1}$ Hemat Sitepu, Revitalisasi Pranata Sosial Pasca Konflik. Maluku (Jakarta: Ciputat Press, 2007).

2 Richard Zacharias Leirissa, "The Bugis-Makassarese in The Port Towns: Ambon and Ternate through the Nineteenth Century: Authority and Enterprise among the Peoples of South Sulawesi," Bijdragen tot de Taal-, Land- en Volkenkunde, Vol. 156, No. 3 (2000), 619-663.

3 M. Chatib Basri and Hal Hill, "Indonesian Growth Dynamics," Asian Economic Policy Review, Vol. 6, No. 1 (2011), 90-107.

${ }^{4}$ M. Chatib Basri, "Twenty Years after the Asian Financial Crisis," in Louis E. Breuer et al. (eds.), Realizing Indonesia's Economic Potential (Washington, D.C.: International Monetary Fund, 2018), 21-45.

5 Alpha Amirrachman (ed.), Revitalisasi Kearifan Lokal: Studi Resolusi Konflik di Kalimantan Barat, Maluku dan Poso (Jakarta: International Center for Islam and Pluralism [ICIP], 2007).

${ }^{6}$ Badrus Sholeh, "The Dynamics of Muslim and Christian Relations in Ambon, Eastern Indonesia," International Journal of Business and Social Science, Vol. 4, No. 3 (2013), 303-311; Gerry van Klinken, "The Maluku Wars: Bringing Society Back In," Indonesia, Vol. 70 (2001), 1-26; Gerry van Klinken, Perang Kota Kecil: Kekerasan Komunal dan Demokrastisasi di Indonesia (Jakarta: Yayasan Obor Indonesia, 2007).
} 
The political shift from an authoritarian regime to a democratic one, policy shift from centralized to decentralized, and split between the police and military forces invited speculation that the country would collapse. Indonesia's loss of the then Timor Timur province (now Timor Leste), which gained its independence through a public opinion poll in 1999, arguably inspired and fostered insurgency group movements in the provinces of Aceh, Papua, and Maluku to demand a chance to leave the unitary state of the Republic of Indonesia. In 1999, a year after the reformation, Maluku was shaken by prolonged communal violence, resulting in an unstable region and a highly distrustful society.

This article tries to elaborate the role of economic activities in everyday peacebuilding, which are reflected by the dynamics of the trade activities in a conflict-prone society which was overlooked in studies related to conflicts in Ambon. This article argues that trade enabled grassroots level interaction among segregated communities and promoted cooperation narratives especially among women. In approaching the problem, the entry point for the fieldwork was the idea of trade points as active and socially functioning spatial entities and how they affected society during turmoil periods. Throughout this article, an analytical timeline of the dynamics of the Ambonese society embedded to interreligious economic activities is explored to obtain an all-encompassing understanding of how the conflict period began, the events of the conflict itself, and the self-reliant local coping strategies used during the conflicts.

The findings for this article derived from qualitative research methods by collecting primary data through interviews and observations. The field research that was undertaken over a 10month period, from July 2017 to March 2018 and June 2018 to July 2018, with additional data obtained in August 2019. General participant observations were mostly conducted at Pasar Mardika (Mardika market). The Mardika market is a three-storey building with the ground floor designated for various commodities, the first floor for clothing stores, restaurants, and beauty salons, and the second floor for second-hand clothing stores and a mosque. The observation setting was expanded to the traders' neighborhoods, farms and gardens, and worship places to get a broader perspective of their socio-cultural aspects. In addition, a considerable amount

${ }^{7}$ Sholeh, "The Dynamics of Muslim," 303-311. 
of time was also spent obtaining pertinent documents and bibliographic materials on related topics.

\section{Communal Conflicts}

The religious struggles in the Moluccan region started with the coming of Islam through trading in the late fifteenth century, long before Indonesia's independence, when Christianity was imposed on the Moluccan population by both the Portuguese (Catholicism in 1512) and the Dutch (Protestantism in 1599). ${ }^{8}$ As a result of these colonial powers, the people in the Moluccas were segregated into monoreligious village units. Due to this, the society had to face sharpened group boundaries along with the existing local power struggles and traditional rivalries. ${ }^{9}$ Further, during the Dutch colonial rule, religious discrimination became a common practice, which is believed to have been the strongest dividing factor. "Christians were given preferential treatment in education and the bureaucracy from the mid-nineteenth century onwards."10 Although both communities tried to maintain religious harmony for decades, residual tension due to the discrimination and previous conflicts lingered among them. Moreover, the religiously segregated neighborhoods established prior to the 1999 conflicts became even more divisive during and after the conflicts. The latent tension between the Muslims and Christians was also strongly apparent in the recent conflicts, wherein Islam represented resistance against the Dutch colonial legacy and Christianity. ${ }^{11}$

With Indonesia's strong claim as being a pluralistic society since its independence in 1945, maintaining social cohesion through religious harmony and fostering economic growth were the main goals of the government during Soeharto's New Order

8 Birgit Braeuchler, "Christian-Muslim Relations in Post-Conflict Ambon, Moluccas: Adat, Religion, and Beyond," in Bernhard Platzdasch and Johan Saravanamuttu (eds.), Religious Diversity in Muslim-majority States in Southeast Asia (Singapore: ISEAS, 2013); Birgit Braeuchler, The Cultural Dimension of Peace: Decentralization and Reconciliation in Indonesia (New York: Palgrave Macmillan, 2015); Leirissa, "The Bugis-Makassarese," 619-663; Sholeh, "The Dynamics of Muslim," 303-311.

9 Richard Zacharias Leirissa, "Social Development in Ambon during the $19^{\text {th }}$ Century: Ambonese Burger," Cakalele, Vol. 6 (1995), 1-11.

${ }^{10}$ Braeuchler, The Cultural Dimension of Peace, 75.

11 Ibid. 
era. ${ }^{12}$ However, feeling like they were being neglected led to frustration among the Muslims and inevitably triggered outbreaks of violence, threatening the religious pluralism of the country. Mukti Ali, the then Minister of Religious Affairs, introduced the concept of agree to disagree, which aimed to promote studies on comparative religion as well as the practice of interreligious dialogue to bring stability to the society. Mukti Ali argued that "interreligious dialogue does not have to focus on theological issues but on the social-religious issues which are at the center of every religious community"13 and that the harmonious coexistence of the various religious communities could be made possible by fostering mutual respect and tolerance. However, these efforts could not forestall the growing intolerance, and outbreaks of ethno-religious communal violence rose in the country after the fall of the Soeharto regime in 1998. Amirrachman argued that the norms and cultural values of the people in Maluku gradually decreased, causing a rise in conflict, and the musyawarab or multistakeholders' dialogue to reach consensus lost its function, resulting in greater distrust among the society members. ${ }^{14}$

Following the history of Moluccan archipelago, the Maluku province was divided into two provinces after the reformation era: The North Maluku province and the Maluku province. When referring to the Maluku province, I refer to its current state, while the Moluccan archipelago refers to all the islands registered in both the provinces. Scholarly debates on the exact date of the end of the conflict periods are to no avail; depending on the methodological approach and disciplinary lenses used, it may be 2002, 2004, or 2011. The physical communal violence in Ambon arguably ended with the signing of the Malino II peace agreement on February 11 and 12, 2002, two months after the Malino I negotiations to resolve conflict in Poso, Central Sulawesi, despite a big riot that erupted just after the delegates arrived back in Ambon. The negotiations were supported by the central government and facilitated by the Minister of People's Welfare

\footnotetext{
12 Herman L. Beck, "A Pillar of Social Harmony: The Study of Comparative Religion in Contemporary Indonesia," Modern Societies and the Science of Religions, Vol. 95 (2002), 331-349.

13 Ibid., 223.

${ }^{14}$ Amirrachman (ed.), Revitalisasi Kearifan Lokal.
} 
Jusuf Kalla and Coordinating Minister of Politics, Legal, and Security Affairs Susilo Bambang Yudhoyono. ${ }^{15}$ A total of 70 representatives, including actors from various backgrounds such as religious leaders, adat (customary) leaders, academics, and grassroots representatives attended the meeting, with an equal number of Muslims and Christians. Top-level national and provincial government officials led the negotiations process. Braeuchler argued that it was one of the first governmentsupported peace initiatives that even partially succeeded in halting the communal violence in Indonesia. ${ }^{16}$

In the following months of 2002, peace and stability were still a distant reality. The pela-gandong ties were cut and interreligious relations were damaged, resulting in the growth of hatred and revenge between the two communities and an increasing number of victims. People were relocated and segregated based on their religion, children grew up surrounded by violence, and education was disrupted by the conflicts. Bombings took place every couple of months, resulting in skepticism among the people about the elite's method of resolving conflicts as it did not seem to work. While various initiatives had been carried out by external actors, including international NGOs and local NGOs, the continuing violence on ground indicated the failure of the government-led peacebuilding approaches. Meanwhile, ceremonial activities to promote peace flourished throughout the years. A peace parade was held around downtown Ambon City, initiated by two pelagandong village communities Hulaleu (Christian) and Kailolo (Muslim), who were arguably the most respected, powerful, and feared groups during the conflicts. The parade ended with a ritual called makan patita (or simply put, eat together) between these two clans, formalizing their reconciliation of past issues. ${ }^{17}$

Meanwhile, the bottom-up approach used by the NGOs, civil society organizations and their economic transactions were considered by the government as the first layer of the

15 Saidin Ernas, "Policy of Social Conflict Resolution: Implementation of the Malino Agreement in Maluku," Jurnal Studi Pemerintaban, Vol. 3, No. 2 (2012), 316-344.

${ }^{16}$ Braeuchler, The Cultural Dimension of Peace.

17 Rachel Iwamony, "The Reconciliatory Potential of the Pela in the Moluccas: The Role of the GPM in this Transformation Process" (Ph.D. Dissertation-Vrije Universiteit Amsterdam, The Netherlands, 2010). 
peacebuilding efforts. The economic interactions allowed them to exercise a basic survival strategy to fulfill their basic needs, and the conflict situation, arguably, did not hinder the Ambonese community from this everyday practice. ${ }^{18}$ However, the relatively stable situation in Ambon was ruined when big riots took place all over the city on April 25, 2004. This time it was linked to the celebration of the Republic of South Maluku (Republik Maluku Selatan-RMS) independence day, which was closely associated to the interests of the Christian community. At least fourty people died during this incident. ${ }^{19}$

It was a moment of truth for the Ambonese people when they realized that they had been used to further the elites' interest. Further, due to the accusations about the strong ties between the RMS and Christians, it came to light that several priests had expressed their disappointment towards the state, implying that the Christians had been used as scapegoats to make it seem like they were the separatists. Waileruny argued that the communal conflicts in Ambon were proof of the state's failure. ${ }^{20}$ It was the tactic of divide et impera (divide and rule) all over again; the Christians were labeled as separatists and the Muslims as jihadi terrorists, while the state could get away with it. In a more practical way, Adam perceived the end result of conflict as the downgrading of the Christians' status in the society as they took up informal and bluecollar jobs, while the Muslims obtained relatively equal access to work in governmental institutions as well as the opportunity to become politicians. ${ }^{21}$ Apart from these, neither party won the conflict; rather, both of the communities were the victims. As most literature on peacebuilding would suggest, one of the most

18 Jeroen Adam, "Downward Social Mobility, Prestige and The Informal Economy in Post-conflict Ambon," South East Asia Research, Vol. 16, No. 3 (2008), 461-479.

19 Rohaiza Ahmad Asi et al., Conflict Management in Indonesia: An Analysis of the Conflicts in Maluku, Papua, and Poso (Geneva: Centre for Humanitarian Dialogue, 2011); International Crisis Group (ICG), Indonesia: Violence Erupts again in Ambon (ICG Asia Reports No. 32/2004) (Jakarta/Brussels: ICG, 2004).

20 Semuel Waileruny, Membongkar Konspirasi di Balik Konflik Maluku (Jakarta, Indonesia: Yayasan Pustaka Obor Indonesia, 2010).

${ }^{21}$ Jeroen Adam, "Displacement, Coping Mechanisms and The Emergence of New Markets in Ambon" (Working paper No. 9, 2008), retrieved from Conflict Research Group <http://www.psw.ugent.be/crg/Publications/working\%20pa pers/workingpaper adam.pdf $>$. 
common practices in building peace involves acknowledging that both sides were the victims.

The year 2004 was chosen as the end of the conflict cycle for this article because the intensity of violence significantly reduced in that year. More importantly, a significant increase in the number of interreligious interactions due to trading activities at the main marketplace, the Mardika market, was seen in this year which was in line with the topic of this article. Furthermore, in the same year, the municipality of Ambon also issued an order for traders at temporary marketplaces, primarily in the Christian areas, to be officially moved to the Mardika market. In this article, the conflict period is established based on the dynamic interplay of trade, marketplaces, and traders on the island. As the findings progress, I combine and adjust the period according to the local understanding of the partition of the conflicts using emic terms such as sebelum kerusuban, waktu masib aman translated into the period before the 1999 conflict, (waktu) panas-panas translated into the heated period of intense violence, su aman-aman (kind of safe) to mark the quiet period in between the violent outbreaks, and $s u$ aman (already safe) for the post-conflict period. This article will only focus on two periods-the sebelum kerusuban, waktu masih aman (prior to) and panas-panas (during) periods.

\section{Positioning Traders in The Ambonese Social Structure}

The situation in Maluku prior to the 1999 outbreak can be best described as the period in between conflicts. The area has gone through various wars in the past; one of the triggers was the race to discover nutmeg in the $16^{\text {th }}$ century. However, no particular patterns or exact intervals can be drawn from one conflict incident to another. On the eve of the outbreak of the 1999 conflicts, the Ambonese society was in a precarious situation. The migrants, commonly referred as BBM (Bugis, Butonese, and Makassarese), were blamed for taking financial and job opportunities from the native Ambonese/Moluccan people. Though it is not openly discussed in daily conversations, the distinction between the migrants (some were called orang dagang, which means people who trade) and native Ambonese (often called anak negeri, which means children of the land) is inevitable. Kadir, in his research on the Butonese traders on Ambon island, argued that orang dagang refers 
to "middlemen, merchants, and traders coming from outside the local society who have contributed to stimulating the local economy." 22

In the case of Ambon Island, the BBM was about to be expelled from the island and sent back to their native origins for they were accused of being the source of the chaos. Meanwhile, in alignment with the common narratives on the trigger of the conflict, a dispute between a Makasarese Muslim migrant minibus driver and native Christian minibus passenger is said to have started off the conflict. Therefore, whether or not it did have an impact on fueling the conflicts, ethnicity, religion, and primordiality allegedly cooked up the beginning of the conflicts in Ambon Island as well as in the Moluccas. To understand why the 1999 conflicts occurred and how they were sustained for a couple of years, let alone escalated, I elaborate on the pre-existing ethnic and interreligious coexistence patterns in the Moluccas, particularly on Ambon. In doing so, several societal elements that coincide in the Ambonese society are elaborated upon such as religion and the economic spheres of life, including the types of traditional economies, trading-related activities, and the dynamics of the marketplace and its actors prior to the conflicts.

The traders in Ambon have always been associated with migrants and the Muslim identity. In everyday conversation, migrant people are referred to as orang dagang (people who trade). These traders who came to Ambon once aimed to reach Banda through the Gorom islands in the eastern part of Seram. Ambon was arguably not the main trade node, especially during the period before the Indonesian independence. Yet, these encounters and interactions through trade made up the ethno-religious diversity in the contemporary Ambon. As per Ellen's understanding of the social interactions embedded in the Moluccan trading activities "there should be an ethnic dimension to trade at all, anywhere,

\footnotetext{
${ }^{22}$ Hatib Abdul Kadir, "Gifts, Belonging, and Emerging Realities Among 'Other Moluccans' During the Aftermath of Sectarian Conflict” (Ph.D. Dissertation-University of California, Santa Cruz, 2017), 106.
} 
arises from the juxtaposition of social and cultural differences that the spatial movement of people brings about". ${ }^{23}$

However, the term orang dagang, which is strongly associated with migrants, sometimes overlaps with the word pendatang, which means migrant in the Indonesian language. Therefore, a relation was suggested when, during the conflicts, a similar line was conveyed by both communities: "Seng apa-apa cuma katong kan bilang, orang luar sa yang biking konflik" which translated to "It was not a problem, we (always) said that it was the outsiders who caused conflicts." If we look closer at the identified conflict actors, the migrants, being outsiders, were pushed out of the island. Despite this, many of them remained on the island and found shelter in the various IDP camps. Second, the orang luar or outsiders could also refer to the Muslim para-militias who were blamed for escalating the Ambon conflict. ${ }^{24}$ However, blaming the outsiders or external actors is a common practice in conflictaffected societies as it results in the opposing communities considering each other as victims and reconciling.

Before the conflicts erupted, marketplaces in Ambon were dominated by Muslim people, with a significant level of migrant representation. There were at least three big markets in the heart of Ambon City: the Mardika market, Batu Merah market, and Pasar Lama market (old market). The Gotong Royong market also survived the conflicts but was gradually abandoned by traders and buyers after the revitalization of the Mardika market. The old Batu Merah market was one of the two oldest markets, located a couple of hundred meters from the current Batu Merah market. The old Batu Merah market was the main market along with the Pasar Lama market. Meanwhile, the Mardika market was built in 1986/1987 on reclamation soil, aimed at becoming the central market in Ambon and replacing the old Batu Merah market.

Prior to the conflicts, it was a common occurrence for the inhabitants of the Mardika village and the Batu Merah Negeri to get involved in fights. The fights usually took place around the time of religious celebrations such as Eid-ul Fitri and Christmas, similar to

${ }^{23}$ Roy Ellen, On the Edge of the Banda Zone. Past and Present in the Social Organization of a Moluccan Trading Network (Honolulu: University of Hawai'i Press, 2003), 260261.

${ }^{24}$ Adam, "Displacement, Coping Mechanisms." 
the beginning of the 1999 conflict. These fights were mostly triggered by the abuse of alcoholic drinks among the young or middle-aged men of both areas. The head of Mardika market unit, a Christian who lived in the Mardika village when he was a kid, recalled such fights between the two areas as a being common and conveyed that people from both sides would throw rocks at each other or get involved in physical fights. However, these fights usually lasted only for a day or two and were followed by a baku bae (an act to befriend one another and leave the troubles behind). Therefore, it took most local people by surprise to witness a fight on 19 January, 1999, which seemed to be a common one, leading to a communal conflict lasting for years in Ambon. As common as they were, the fights and rock-throwing incidents did not hinder women from gaining access to each area's market; it was business as usual.

The conflicts forced people to rejoin their homogeneous religious identity groups, turning Ambon Island into a collection of religiously uniform villages. The areas that had been previously inhabited by mixed communities either became borderline areas or only welcomed residents with a particular religious identity. During the conflict, the majority of the inhabitants of the Batu Merah area were Muslim, whereas the Mardika village was predominantly a Christian area. To avoid any confusion, the Mardika market was and is dominated by Muslim traders, but the rest of the village is inhabited by the Christians. Meanwhile, the Batu Merah market was once a mixed-religion area with Christian inhabitants as well, but they fled or were evacuated to neighboring Christian areas such as Karang Panjang when the first riot broke out.

Tension and resentment towards the migrants in Ambon were prominent in various degrees, from subtle sarcasm to confrontations. At the time, the ethno-religious labor division between the informal and formal positions was quite distinguishable, where migrants occupied mostly informal jobs and native Ambonese especially the Christians took up the formal jobs. This gap did not immediate incite tensions between the members of the different communities. This could also be explained by the authoritarian policies imposed by the Central Government that gave no room for the citizens to challenge their status quo. The society was already mentally segregated one way or another. In his article, 
Adam revealed how the Christians started to take up informal jobs during the conflicts, and this socio-economic shift is present even today. Before the conflicts, the pedicab drivers were mostly Muslim migrants from Sulawesi Island. Motorcycle drivers, although few in number, were also Muslim migrants. This socioeconomic landscape significantly changed during the conflicts. ${ }^{25}$

This division of societal roles supports the argument that traders are mostly members of ethnic or religious minorities, particularly migrant communities. The migrant communities struggled to fully integrate into the host society. They still experience active discrimination due to the social and cultural differentiation and are believed to "not share the moral values of "civilized society." 26 The accumulation of this feeling of exclusion and being discriminated against cemented the latent tensions between the migrants and natives. As they usually interacted for the purpose of economic transactions, the marketplace then inevitably became the place where the tensions arose. However, the marketplace and trade points also provided a space for interreligious coexistence in Ambon.

\section{The Tense Periods}

The major religious hostilities began in Ambon City and then spread out among other areas of the Moluccas. Just like other communal conflicts, there were periods during which quickly tension escalated into communal fighting, bombing, murders, and other types of physical violence. There were also times when the situation was relatively stable and no unrest broke out, but the people were unsure whether the conflicts had indeed abated. The three years leading up to the formal peace agreement of Malino II in 2002 signified the period during which the Moluccas and North Moluccas became battlefields for conflict as well as peacebuilding interventions. Locals referred to this period as "waktu [masib] panaspanas" (when it was [still] highly tense). Some argue that the transition to the peace period began immediately after the first unrest in January 1999. Others define the transformation period as

\footnotetext{
25 Ibid.

${ }^{26}$ Hans-Dieter Evers and Heiko Schrader, The Moral Economy of Trade: Ethnicity and Developing Markets (London and New York: Routledge, 1994), 8.
} 
having started after the physical violence significantly reduced in 2004.

Most of the damages occurred during the waktu panas-panas period. People were shocked and could not rightfully understand how to cope with the situation. The military interventions did not seem to gain the trust of either community to stop the violence. Instead, distrust and competition over power underlined the relationship between the military and police forces. When Megawati came to power in 2001 as a civilian president, it inevitably invited further skepticism about her ability to resolve the communal conflicts in five provinces of Indonesia: West Kalimantan, Central Kalimantan, Central Sulawesi, North Maluku and Maluku. ${ }^{27}$ From a political view, this was a test for Megawati. The reformation era seemed to cut loose the military power, leaving them handicapped; they were no longer part of the House of Representatives, and the police force, which was once under their control, became an independent institution. Various speculations led people to believe that the prolonged conflicts were induced on purpose. Mass media was biased along the religious line, making the situation even worse with constant provocative news building the conflict-related narratives. One of the peacebuilding efforts in the early conflict period was to establish independent media outlets for factual and neutral news production. The local and central governments, being authoritative institutions, tried to calm down the enraged communities by visiting them and conducting dialogues with the victims of the conflicts.

During this period, people were displaced to areas that were predominantly homogeneous in their religious beliefs. Some stayed at their relatives, friends, or community/religious leader's houses. Many conflict narratives also revolved around how people voluntarily accepted strangers into their houses as well as how some of them tried to save and hide people of other religious beliefs at their houses. The rest of the conflict-affected society members had to stay in IDP camps. The IDP camps first emerged as temporary shelters until the situation became conducive to peace. It was both the initiative of victims stranded in particular locations as well as a top-down offer for people to stay at

${ }^{27}$ Van Klinken, Perang Kota Kecil. 
institutional offices, military headquarters, religious worship places, and other public places such as hospitals, schools, and the Mardika market. Other groups chose to flee to a neutral area called the Wayame village. This area remained a mixed ethno-religious area over the course of the conflicts. The Wayame inhabitants refused to engage in any provocative actions that would divide their people. Tony Pariela, an Ambonese academic, argued that this village expanded the roles of preserved social capital as the basis of a survival strategy that helped them to overcome the external threat. Pariela also highlighted the roles of the mixed market in this village as enabling the smooth integration of people for conducting safe exchanges, which helped re-build the trust between the Muslims and Christians through trading. ${ }^{28}$

\section{Informal Economies and Attempts to Build Peace}

Most literature on the conflicts focus on the physical violence, political stance, and peace agreement, but scant attention has been paid towards understanding the ordinary life of the people when the physical violence was on hold. People needed food to survive, which was a different kind of battle that they needed to win. This battle was mainly dealt with by the women.

Prior to the 1999 conflicts, the Muslim residences were spread out in the northern part of Ambon island, which was later known as the Jazirah area (peninsula) or Leibitu region. Meanwhile, the Christian residences occupied most of the southern part of the island, which was often referred to as the Leitimur peninsula. Economy-wise, the Leitimur, that is, the Christian areas, were home to many business premises, including important markets, supermarkets, and vital governmental offices. Most of the successful sellers, traders, and merchants were either Muslim migrants (identifying as Bugis, Butonese, or Makassarese people) or Chinese; the native Christian Ambonese primarily worked in the service sector or government offices. There were several areas that are of mixed-religion, sometimes in the form of enclaves within the Christian areas. The existence of those mixed-religion areas shows that the communities co-existed with a relatively stable

\footnotetext{
28 Tonny D. Pariela, "Damai di Tengah Konflik Maluku: Preserved Social Capital sebagai Basis Survival Strategy" (Ph.D. Dissertation--Universitas Kristen Satya Wacana, Salatiga, 2008).
} 
relationship, regardless of the prominent gaps in the educational levels, formal job opportunities, and political power that could potentially spark social jealousy.

\section{Muslim Communities and Border Trades}

As far as the Ambonese people can remember, the main Mardika market was the Muslims' major source of income. During the conflict period, it was once burned down in the beginning of the conflict period-allegedly by the Christians, but this was never proven. It caused stronger negative sentiments among the Muslim people towards the Christians. After being burned down, the Mardika market area was closed to the public and was used for activities other than exchanges; it consisted of a temporary military post, IDP camp for the Butonese and other migrants, and other abandoned parts. The market areas were enclosed within a barbed wire fence and a sign that said "Restricted Area, No Trespassing." Discourse around the market's burning took place every day. This is understandable since the market was the core of the Ambonese society and was also a symbol of power and security for the Muslims. Further, a lot of people lost their main source of income due to the incident.

During the waktu panas-panas period, trade routes were mostly shifted in the Muslim and Christian areas with most roads had been barricaded, especially in the borderline areas. The barricade aimed to mitigate any contact between the conflicting parties. As for buyers and sellers, the barricades forced them to use alternative routes to reach their destinations. The same applied for trucks carrying goods to be distributed in the Christian or Muslim areas as well as minibuses carrying passengers.

"For example, if it was tense here (di sini lagi panas), the road was most likely barricaded in Galunggung-Batu Merah. So, it means that the basudara/non-Muslim brotherhood would have to pass by the hills. Those who came from Passo, Batu Gong, they came out from Belakang Soya-that was the route-so during the riots they passed by there." 29

Difficulties were often encountered while reconstructing the routes as the respondents were unable to go beyond their personal spatial experiences, which inevitably limited their ideas about the

${ }^{29}$ Interview with Taufiq, Ambon, January 1, 2018. 
situation in the segregated areas. A female respondent, Wa Rohmah, who used to sell vegetables at Mardika market explained that prior to the conflicts she went down to the Poka port by taking the minibus or a jointly chartered truck with her farmer/seller neighbors. If she took the minibus, she had two options to get to the market: by following the minibus route around the coastline and then downtown or getting off near the port and crossing the strait by ferry or a small wooden boat. If she took the chartered truck, one of the above options would be chosen by the driver. Although there were other trade points nearby, she always went to the main market because she had already earned a place there, and she was afraid that somebody else would take her spot if she did not show up. Additionally, she had a greater chance of selling out her goods at the main market. Throughout the conflict period, Wa Rohmah continued to sell her surplus garden products to the nearby markets, usually at the Rumah Tiga market near the Poka port, she did not go to the main market/Mardika market as it was too dangerous for her to cross the strait.

"Oh, in the past, when I used to trade, I took the wooden boat ... crossed to Galala, then got on the minibus to the market... it was when it was still safe." ${ }^{30}$

During the panas-panas period, various strategies were used by the Muslim sellers. A female seller, Wa Intan, shared four possible strategies that she used to distribute and sell her commodities. From her house, she walked up the hill then down to Wayame market, a mixed village where Muslims and Christians were both welcome. If the business was good, she would directly return home after selling her goods. Otherwise, she would take the speedboat to the Batu Merah market, a functioning market located next to the Mardika market. Alternatively, instead of going up the hill and down to the Wayame market, she would take another route to the Rumah Tiga trade point. This trading point was established next to the Rumah Tiga speedboat port during the conflict period to accommodate sellers who needed to go directly to Batu Merah without stopping at the Galala ferry port. At first, only a few sellers decided to set up stalls around the temporary speedboat port at Rumah Tiga. However, in just a few months, an

${ }^{30}$ Interview with Wa Rohmah, Ambon, January 25, 2018. 
increasing number of sellers took the same route to the Batu Merah market, and some of them decided to end their journey at the Rumah Tiga trade point. Similar patterns were also found among the sellers at several temporary speedboat ports; the sellers occupied the space surrounding the port and reshaped the space according to their needs, such as the Benteng market.

Also, during this period of active violence, the speedboat service was the most suitable transportation method that enabled them to travel across the sectarian boundaries. As illustrated in the excerpt below, the trade in the main Batu Merah market was only made possible through the speedboat services. The speedboat services were privately owned by individuals or informal companies. Public sea transport was also available to link Poka and Galala with a ferry. When the conflicts escalated, the ferry and speedboat services had to be re-routed to avoid areas where riots took place, and the ferry service operation ceased during the panaspanas period or when it was too dangerous to cross the conflict areas. In addition, the speedboat routes were multiplied to adapt with the then locational arrangement, especially for connecting religiously homogeneous areas. The routes differed based on the areas being connected; i.e., between two residential areas or between residential areas and marketplaces or trading points.

"At that time, Muslims have already been back to Rumah Tiga, then cross by using speedboat to Batu Merah, goods, people, like that, all by speedboat ... labor, labor, picking up goods from the car we put them to the speedboat. From us in Rumah Tiga, that time, then from speedboat from the city, we took the goods to the cars, then they brought them to Hitu, those who would go to Seram, you know." 31

\section{The Emergence of Christian Sellers and Temporary Trade Points (Pasar Kaget)}

Although contact avoidance was relatively strong in Ambon during the panas-panas period, there were some spaces in which the two communities could interact. Inter-religious contact in Ambon was not limited to meeting on college campuses or at schools but also occurred in places such as markets and hospitals over the

${ }^{31}$ Interview with La Adin, Butonese, Ambon, January 25, 2018. 
course of everyday life. ${ }^{32}$ This subsection outlines the emergence of temporary markets in the Christian areas as a result of the blockade to the regular markets, which were located in Muslimdominated areas, and how the new trading node impacted the Ambon trade routes. Ethno-religious identities play a prominent role in these issues. Contrary to the belief that the Ambon conflicts were between the Muslims and Christians, these two groups showed discreet but extensive cooperation in their trading activities, especially for intervillage goods distribution.

"Yes, we had to transfer [through] sea transport ... on our side, we already built our own market, but sometimes people like us, we re-grouped [to go to the main market]. It was quite common because the Muslims, we had transactions at the borderline to buy chili pepper, tomato, they sold to our people ... apparently, they conducted the borderline transactions with the guard from the military forces." 33

Tante Jessica stated that although the Christian communities began building their own temporary marketplaces, they would visit the Mardika market during quiet periods. She also mentioned the emergence of borderline trade points where Muslims and Christians met to conduct transactions, especially vegetable exchanges. In a segregated society like Ambon, the borderlines become the battlefields during conflicts as each side fights to enter their opponent's zone; these were the thin margins that separated them. However, due to the same logic, the borderlines often became the most eligible spaces for interreligious interactions to take place, especially in the form of exchanges, barters, or economic transactions, because each side could easily back away into their respective zones if a conflict took place. These borderlines were perceived as being chronically violent places; over the course of the conflicts, the very same spaces were transformed into relatively controlled areas with reduced violence due to the presence of official military guards and the building of official military posts. This understanding indicates the importance of considering the time dimension of economic transactions in times of conflict, such as how the borderlines switched from being

\footnotetext{
32 Cahyo Pamungkas, "Intergroup Contact Avoidance in Indonesia" (Ph.D.

Dissertation--Radboud University, Nijmegen, the Netherlands, 2015).

${ }^{33}$ Interview with Tante Jessica, Ambon, June 18, 2018.
} 
battlefields to contact enabling spaces. The trade points were often referred to as the baku dapa spaces-baku means "with each other/to each other" and dapa (or "dapat" in the Indonesian language) means "to get"; together, they mean "to meet up."

The number of traders in Ambon City declined during the conflict period, it then rose steeply as the temporary markets in the Christian areas mushroomed. However, the number significantly decreased, once again, in 2003, following a relatively stable situation in Ambon with people being able to access markets in both the Muslim and Christian areas. Most of the narratives related to this period convey that the physical violence had significantly reduced, and the state of civil emergency signed on June 27, 2000, by President Abdurrahman Wahid was lifted on September 15, 2003.

The number of mobile peddlers (small-scale traders) who sold their commodities by walking around various villages decreased once people stopped being afraid to visit the markets. The goods sold by the mobile peddlers were more expensive than those at the temporary markets, and the prices were significantly lower at the main market. Various initiatives to maximize the role of economic exchange in fostering peace had also been established for a while. The programs were initiated by the Baku Bae Movement, Peace Circle for Women and Children, and other NGOs, aimed at enhancing and multiplying interreligious interactions among the female traders. Three "peace" markets were built and inaugurated under the framework of the Baku Bae Movement: the Baku Bae Market (now the Mardika market), borderline trade points at Pohon Pule, and borderline trade points at Nania village. The interview excerpt below describes the emergence of trade points outside the main market as well as the interreligious interactions aimed to fulfill the people's daily needs.

"The people initiated what was called the markets [many markets]. Transactions actually happened outside of the market... in spaces for baku dapa [meeting each other] that were safe for them to interact with each other such as Amans Hotel, Military Hospital, and, finally, they came to the markets with their goods. The Muslims brought fish, the non-Muslims came with other stuff, then the goods were sold there; they conducted 
the exchanges there. And then, those spaces were transformed into the Baku Bae market." 34

Since the Muslim farmers and traders could not sell their products to Christian buyers during the conflicts, they had to develop other networks - they conducted their trade in the frontiers, went to the neutralized market in Wayame, or gained a connection to the Seram Island areas. Meanwhile, the Christian side had to find ways to access the food supply either from within Ambon or outside the islands. The spatial segregation also forced the supply distribution routes to become distorted, slowing down the process. It impacted the emergence of transit points for goods distribution and later fostered the emergence of temporary markets in the Christian areas.

As mentioned earlier, one of the most common income generating strategies during the conflicts was petty trade, which resulted in a "surprise [temporary]" market (Pasar kaget). These Pasar kaget were built in each religious community's area. Furthermore, Adam elaborated on two types of trading in Ambon. "The first type is 'outside' selling defined as 'activities in marketplace down the road or by walking around with a mobile stall" while the second type of activity comprises of "inside" selling activities or trading activities that took place at home or at least inside the walls of the camp." 35 Similarly, Van Klinken viewed the market activities in Ambon as being part of the informal economy that helped the two communities to cope with their lives during the conflict for Ambon City was subject to institutional collapse, resulting in the loss of almost all the traditional state authorities. $^{36}$ On the bright side, this situation created opportunities for people to start markets in the city, regardless of the area. The interview excerpt below shows that the government allowed the establishment of new markets in Ambon and saw them as having the potential to reduce the tension during the conflicts.

"Let the market grow; give them [capital] incentives. People should be equipped to be innovative... now that they are trading,

\footnotetext{
34 Interview with Ca Mina, Jakarta, July 11, 2018.

35 Adam, "Displacement, Coping Mechanisms," 6.

36 Van Klinken, "The Maluku Wars."
} 
we should just let them do it for as long as it continues; management and regulations should come later." ${ }^{37}$

The then mayor of Ambon, Marcus Jopie Papilaja (r. 20012011) introduced a significant policy which touched upon the idea of creating "point centers" in a number of safe places in Ambon. These points of trade were aimed at allowing economic transactions that involved Christians and Muslims. In addition, to provide a guarantee of security, the mayor ordered security officers to safeguard the locations. Al Qurtuby stated, "During the riots, ordinary Christians and Muslims found it difficult to purchase food and sell their wares since the main traditional markets were on fire and ruined. They were also afraid of carrying out economic activity in these devastated traditional markets." 38 These centers later became the so-called Pasar kaget. However, the roles of Pasar kaget were fluid and dynamic both positive and negative towards peacebuilding. The positive side was, for instance, the mayor believed that trading activities involving people from various backgrounds would allow them to communicate with one another and build trust, which is the basic capital for reconciliation. On the other hand, with the development of the Pasar kaget, the mayor's initial intention of enabling communal interactions failed. In contrast, the Pasar kaget became tokens of religious segregation in Ambon during the conflicts and at the beginning of the transformation period. Over the course of the years, the traders at the pasar kaget became protective of their status quo and refused to be relocated to the mixed market to the extent that they monopolized access to goods in the Christian areas. Such practice hindered possible interreligious interactions between the Muslims and the Christians to take place through economic exchanges.

\section{Trade, Traders and Peace Narratives}

In this panas-panas period, people chose to not venture outdoors for a while, waiting for the threat to be over. People had no options than to buy goods either at temporary markets or from mobile peddlers. The term papalele was used for female traders wearing traditional clothes and jibu-jibu for Muslim fish peddlers.

\footnotetext{
${ }^{37}$ Interview with Vice Mayor of Ambon City, January 2018.

${ }^{38}$ Sumanto Al Qurtuby, Religious Violence and Conciliation in Indonesia: Christians and Muslims in the Moluccas (London, England: Routledge, 2016), 157.
} 
The difference between the two types of sellers lay in the type of goods they sold - a papalele sold fruit and vegetables, whereas a jibu-jibu sold fish. It is widely known that these two types of sellers were female peace agents, and most of the literature emphasizes the gender perspective embedded in their roles. ${ }^{39}$

The roles of the women during the conflict periods were prone to be undermined as they primarily appeared to be victims. Women were conflated with children into one concept: "womenand-children." The loss of their men-folk (husbands, fathers, sons) in the conflicts forced the women to take over the breadwinner role. Despite the negative impact of conflicts on women, Adam (2008) argued that the situation empowered some women and led them into the public sphere, enabling them to engage in activities previously designated only for men. The activities included being a member of the armed movement, trading in the market for economic survival, or becoming actively engaged in peacemaking, among others. In the case of Ambon, the women reportedly led various interreligious peace dialogue efforts at the grassroots level. ${ }^{40}$ However, when it came to formal measures, the women had little involvement in the peace table talks. ${ }^{41}$

The excerpt below is an example of a peace message extended by women to their male relatives, including their husbands and sons, as well as to their acquaintances. Women's peace narratives mostly emphasized how difficult life was during conflicts and the suffering they had to endure.

"We should not take part in the conflicts ever again. We should not take part in the conflicts ever again. What has already happened, we must learn from them. Because we cannot live

\footnotetext{
39 Simon Pieter Soegijono, "Papalele: Potret Aktivitas Komunitas Pedagang Kecil di Ambon" (Ph.D. Dissertation--Universitas Kristen Satya Wacana, Salatiga, 2011); Simon Pieter Soegijono, "Papalele: The Forgotten Campaign," Advances in Social Science, Education and Humanities Research (ASSEHR), paper presented at International Conference on Religion and Public Civilization, 2018; Maria Katje Tupamahu, "Analisis Perilaku Ekonomi Kelompok Perempuan Papalele di Ambon” (Ph.D. Dissertation--Universitas Hasanuddin, Makassar, 2012).

40 Mohammad Hasan Ansori et al., Post-Conflict Segregation, Violence, and Reconstruction Policy in Ambon (Jakarta, Indonesia: The Habibie Center [THC], 2014); Braeuchler, The Cultural Dimension of Peace.

${ }^{41}$ Asi et al., Conflict Management in Indonesia.
} 
like this forever. We need to eat, so we should get better [in life].

Other people go to war. But we should not join the war." 42

It sounds like a simple message. But this message was powerful during the time of uncertainty. In times of war, especially during communal conflicts with the enemies being familiar people, the community members were unsure of who to trust, which message was accountable, and what to believe. Since women hold a special position in the Ambonese society, inherited by tradition, their words were respected and listened to. Therefore, this seemingly simple message was believed to have a strong impact on familylevel violence prevention.

Such an appeal to cease violence was also extended by female traders during their trading activities. Adam and Peilouw argued that informal jobs, such as small-scale trade, became the main source of household income, especially for internally displaced people (IDPs) in two camp areas during the conflict and transformation periods. ${ }^{43}$ Women, in general, were forced to the forefront to undertake economic transactions and fulfill their daily household needs as the men faced greater difficulties and dangers during this time. ${ }^{44}$ To this regard, the role of female traders during the conflicts was increasingly discussed. Muslim women felt safe to walk around the conflict-prone areas due to the common knowledge that women and children would be protected as, according to Islamic teachings, hurting women and children during a war is a huge sin. Ironically, these female traders were accused of being spies for the Christians and faced threats from their fellow Muslim groups. If found selling goods to the Christians, their goods would be confiscated and discarded. Any exchange information of between religiously heterogeneous traders was seen as a threat which could lead to the act of killing.

People said that the market once had a religion-it was common to differentiate between "Christian market" and "Muslim market." This not only applied to the market but the origin of the commodities as well. For example, fish obtained from the Chris-

\footnotetext{
${ }^{42}$ Interview with C. Mina, Muslim Ambonese, Ambon, July 11, 2018.

43 Jeroen Adam and Lusia Peilouw, "Internal Displacement and Household Strategies for Income Generation: A Case Study in Ambon, Indonesia," Social Development Issues, No. 2 (2008), 78-89.

44 Adam, "Downward Social Mobility," 461-479; Adam and Peilouw, "Internal Displacement," 78-79; Soegijono, "Papalele."
} 
tian areas were considered as "Christian fish" and vice versa but it did not last for long time. In the beginning of the conflict, when trust was gravely shattered, distinguishing the origin of commodities became a means to protect oneself from any possible danger, i.e. each community was afraid that the food was poisoned by their counterpart.

Another example is the shift of trade points to marketplace in Benteng village. The village was once inhabited by diverse communities. It shares a border with the Muslim area and was considered as a strategic place for the Christian people to reside in during the conflict. Benteng hosts the second port on Ambon. This port is operated by the Pertamina, a national oil company, and is meant to only allow oil ships to dock. Due to the strategic littoral landscape of this area, the people of Benteng started to open their food and commodity businesses along the coastline. Not long after the conflict erupted, it became an alternative speedboat port that provided access to other Christian villages. As more farmers, traders, food middlemen from outside of the area were gathered there, local people started to buy goods from them or exchanged their food crops for other commodities. This process led to the emergence of the Benteng market that continues to exist in the present day.

Apart from the heavy narratives of violence and death, there are also various stories on interreligious cooperation during the conflicts. The extended social capital built over a long period of time eventually helped them to find sanctuary during the conflicts. A Christian woman who used to live in Silale-Waihaong, which is now a predominantly Muslim area, recounted how she had been saved by her Muslim neighbors during an attack in their neighborhood. She had been separated from her husband and kids and later found out that they had also been sheltered by a different Muslim family. A similar account was also given by a Muslim respondent, who recalled his experience of living in a Christian house for a while because of a blockade that surrounded his residential neighborhood. He was grateful for the help of the Christian neighbor who risked his life to protect the Muslim family. During the interview, he emphasized that not all Christians were bad, and similarly, not all Muslims were bad. 


\section{Conclusion}

This article explored the relationship between the time and spatial dimensions in an ever-changing conflict-prone society over two periods, namely sebelum kerusuban, waktu masib aman (the period prior to the conflict) and (waktu) panas-panas (the conflict-prone period). I distinguished between trade and marketplace, why the spatial extent matters, and how it functions in the broader context of a religiously segregated society. For the marketplace, space as a physical boundary is crucial for its economic function. The findings suggest that the location of a marketplace requires a spatial story and cannot be any place. Similarly, spatial stories also enhance the functioning of trade points; in some cases, they are related to interreligious encounters at the borderlines.

The Ambonese society was deeply segregated during the conflicts. The sectarian boundaries hindered most aspects of the daily life of the people. Children could not go to school, employers were too afraid to go to their offices, especially those whose offices were located in the opposite religious area, and in general, people could not access the markets to fulfill their daily needs. Prior to the conflicts, there was a significant number of mixedreligion areas. As the conflicts grew in intensity, it became dangerous to trespass certain areas, and it was almost impossible to live in an area inhabited by a community of the opposite religion. The stories and identities embedded in each village forced the Ambonese to redefine the extent of their spatial knowledge. These spatial boundaries later became the reference for each community member to move about safely and conduct their everyday activities; words became infrastructure, and stories signified spaces.

The findings reveal the shifting of trade routes used by sellers, buyers, and merchants/distributors during the conflicts. The trade routes and the emergence of temporary markets in the Christian areas revealed that the Ambonese communities developed a local coping mechanism by cultivating their home gardens, peddling, and trading. Social networks and cultural ties as well as the economic drivers of trade-related activities arguably set the foundation for a more structured conflict transformation. Economic transactions allowed interethnic, intervillage, and interreligious interactions to take place, eliminated distrust among the traders, and potentially extended peace message narratives at the micro 
level, i.e., the family level. One of the most important aspects was the revival of local wisdom and the cultural pact that created bond between the Muslim and Christian villages, locally called pelagandong.

In addition, the women of Ambon played an important role in the local peace and reconciliation processes between the Muslim and Christian communities. During the panas-panas period, women regularly traveled to markets to buy or sell products. Muslim traders, especially, visited the main market, which was the Batu Merah market at the time. However, their main reasons for contributing to the reconciliation initiatives were rooted in the need to survive rather than being conscious attempts to resolve the conflicts.

\section{Bibliography}

\section{Books, Articles, and Websites}

Adam, Jeroen and Lusia Peilouw. "Internal Displacement and Household Strategies for Income Generation: A Case Study in Ambon, Indonesia," Social Development Issues, No. 2, 2008.

Adam, Jeroen. "Displacement, Coping Mechanisms and The Emergence of New Markets in Ambon," working paper No. 9, 2008, retrieved from Conflict Research Group $<$ http://www.psw.ugent.be/crg/Publications/working\%20pa pers/workingpaper adam.pdf $>$.

"Downward Social Mobility, Prestige and The Informal Economy in Post-conflict Ambon," South East Asia Research, Vol. 16, No. 3, 2008.

Al Qurtuby, Sumanto. Religious Violence and Conciliation in Indonesia: Christians and Muslims in the Moluccas. London, England: Routledge, 2016.

Amirrachman, Alpha (ed.). Revitalisasi Kearifan Lokal: Studi Resolusi Konflik di Kalimantan Barat, Maluku dan Poso. Jakarta: International Center for Islam and Pluralism [ICIP], 2007.

Ansori, Mohammad Hasan et al. Post-Conflict Segregation, Violence, and Reconstruction Policy in Ambon. Jakarta, Indonesia: The Habibie Center [THC], 2014. 
Asi, Rohaiza Ahmad et al. Conflict Management in Indonesia: An Analysis of the Conflicts in Maluku, Papua, and Poso. Geneva: Centre for Humanitarian Dialogue, 2011.

Basri, M. Chatib and Hal Hill. "Indonesian Growth Dynamics," Asian Economic Policy Review, Vol. 6, No. 1, 2011.

Basri, M. Chatib. "Twenty Years after the Asian Financial Crisis," in Louis E. Breuer et al. (eds.), Realizing Indonesia's Economic Potential. Washington DC: International Monetary Fund, 2018.

Beck, Herman L. "A Pillar of Social Harmony: The Study of Comparative Religion in Contemporary Indonesia," Modern Societies and the Science of Religions, Vol. 95, 2002.

Braeuchler, Birgit. "Christian-Muslim Relations in Post-Conflict Ambon, Moluccas: Adat, Religion, and Beyond," in Bernhard Platzdasch and Johan Saravanamuttu (eds.), Religious Diversity in Muslim-majority States in Southeast Asia. Singapore: ISEAS, 2013.

-----. The Cultural Dimension of Peace: Decentralization and Reconciliation in Indonesia. New York: Palgrave Macmillan, 2015.

Ellen, Roy. On the Edge of the Banda Zone: Past and Present in the Social Organization of a Moluccan Trading Network. Honolulu: University of Hawai'i Press, 2003.

Ernas, Saidin. "Policy of social Conflict Resolution: Implementation of the Malino Agreement in Maluku," Jurnal Studi Pemerintahan, Vol. 3, No. 2, 2012.

Evers, H-D., \& Schrader, H. The Moral Economy of Trade: Ethnicity and Developing Markets. London and New York: Routledge, 1994.

Glass, Pepper G. "Using History to Explain the Present: The Past as Born and Performed," Ethnography, Vol. 17, No. 1, 2015.

International Crisis Group (ICG). Indonesia: Violence Erupts again in Ambon (ICG Asia Reports No. 32/2004). Jakarta/Brussels: ICG, 2004.

Iwamony, Rachel. "The Reconciliatory Potential of the Pela in the Moluccas: The Role of the GPM in this Transformation Process." Ph.D. Dissertation--Vrije Universiteit Amsterdam, The Netherlands, 2010.

Kadir, Hatib Abdul. "Gifts, Belonging, and Emerging Realities Among 'Other Moluccans' During the Aftermath of Sectarian 
Conflict." Ph.D. Dissertation--University of California, Santa Cruz, 2017.

Leirissa, Richard Zacharias. "Social Development in Ambon during the $19^{\text {th }}$ Century: Ambonese Burger," Cakalele, Vol. 6, 1995.

----- "The Bugis-Makassarese in The Port Towns: Ambon and Ternate through the Nineteenth Century: Authority and Enterprise among the Peoples of South Sulawesi," Bijdragen tot de Taal-, Land-en Volkenkunde, Vol. 156, No. 3, 2000.

Pamungkas, Cahyo. "Intergroup Contact Avoidance in Indonesia." Ph.D. Dissertation--Radboud University, Nijmegen, the Netherlands, 2015.

Pariela, Tonny D. "Damai di Tengah Konflik Maluku: Preserved Social Capital sebagai Basis Survival Strategy." Ph.D. Dissertation--Universitas Kristen Satya Wacana, Salatiga, 2008.

Sholeh, Badrus. "The Dynamics of Muslim and Christian Relations in Ambon, Eastern Indonesia," International Journal of Business and Social Science, Vol. 4, No. 3, 2013.

Sitepu, Hemat. Revitalisasi Pranata Sosial Pasca Konflik Maluku. Jakarta: Ciputat Press, 2007.

Soegijono, Simon Pieter. "Papalele: Potret Aktivitas Komunitas Pedagang Kecil di Ambon." Ph.D. Dissertation--Universitas Kristen Satya Wacana, Salatiga, 2011.

----- "Papalele: The Forgotten Campaign," Advances in Social Science, Education and Humanities Research (ASSEHR), paper presented at International Conference on Religion and Public Civilization, 2018.

Tupamahu, Maria Katje. "Analisis Perilaku Ekonomi Kelompok Perempuan Papalele di Ambon." Ph.D. Dissertation-Universitas Hasanuddin, Makassar, 2012.

Van Klinken, Gerry. "The Maluku Wars: Bringing Society Back In," Indonesia, Vol. 70, 2001.

-----. Perang Kota Kecil: Kekerasan Komunal dan Demokrastisasi di Indonesia. Jakarta: Yayasan Obor Indonesia, 2007.

Viterna, Jocelyn. "Negotiating the Muddiness of Grassroots Field Research: Managing Identity and Data," in Martha K. Huggins and Marie-Louise Glebbeek (eds.), Women Fielding Danger: 
Negotiating Ethnographic Identities in Field Research. Lanham, MD:

Rowman \& Littlefield Publishers, 2009.

Waileruny, Semuel. Membongkear Konspirasi di Balik Konflik Maluku.

Jakarta, Indonesia: Yayasan Pustaka Obor Indonesia, 2010.

\section{Interviews}

Ca Mina, Muslim Ambonese, Jakarta, July 11, 2018.

La Adin, Butonese, Ambon, January 25, 2018.

Tante Jessica, Ambon, June 18, 2018.

Taufiq, Ambon, January 1, 2018.

Vice Mayor of Ambon City, Ambon, January 2018.

Wa Rohmah, Ambon, January 25, 2018. 